\title{
CORRELATION BETWEEN SEVERITY OF ALCOHOL DEPENDENCE WITH AGE OF ONSET AND FAMILY HISTORY AMONG URBAN ALCOHOLICS: A CROSS-SECTIONAL STUDY
}

\author{
Hariharan Palaniappan ${ }^{1}$, Alexander Gnanadurai William James², Arunkumar Annamalai ${ }^{3}$ \\ ${ }^{1}$ Assistant Professor, Department of Psychiatry, Government Stanley Medical College, Chennai. \\ 2 Professor, Department of Psychiatry, Government Stanley Medical College, Chennai. \\ ${ }^{3}$ Research Officer, Department of Psychiatry, Government Stanley Medical College, Chennai.
}

ABSTRACT
BACKGROUND
A potentially powerful predictor of progression to alcohol-related harm is age at first use. Evidence suggests that the earlier the
age at which young people take their first drink of alcohol, the greater the risk of abusive consumption and the development of
alcohol related disorders. Equally important is the family history of alcoholism, which is associated with early age of drinking.

AIM

This study specifically aims to explore the relationship between severity of alcohol dependence with family history of alcoholism and age of onset of alcohol use.

\section{MATERIALS AND METHODS}

For a period of six months, we conducted a cross sectional study among 200 male subjects aged between 20-50 years who reported the alcohol and drug dependence clinic of a tertiary care hospital in Chennai, Tamilnadu State with problem drinking in the past one year. We used Alcohol Use Disorder Identification Test (AUDIT), Clinical Institute Withdrawal Assessment for Alcohol (CIWA-AD), Severity of Alcohol Dependence Questionnaire (SADQ), Family History Method, and Schedule for Clinical Assessment in Neuropsychiatry (SCAN) for assessment. 123 subjects were Family History Positive (FHP) and 77 were family history negative (FHN). The data was analysed using a computerized Statistical Software programme (SPSS version 20.0 for windows). Descriptive statistics was used to describe the socio-demographic variables. Student $t$-test was used to compare between ordinal groups. Pearson's correlation was used for assessing the correlation between the variables.

\section{RESULTS}

The mean severity scores were significantly different between the early age of onset and late age of onset groups. The mean current age in the FHP was $38.61 \pm 8.59$ and $42.12 \pm 6.90$ in FHN. The Mean AOO in the FHP was $22.89 \pm 4.61$ and in the FHN was $26.51 \pm 26.51$ and was significantly different from each other $(\mathrm{P}<0.000)$. The Mean SADQ score were $44.59 \pm 10.79$ in FHP and $38.96 \pm 11.50$ in the FHN. This was also significantly different between the two groups $(\mathrm{P}<0.001)$.

\section{CONCLUSION}

The two key findings of this study are that alcoholism severity is related to family history of alcoholism and also age of onset of alcoholism independent of each other.

\section{KEYWORDS}

Family History Positive (FHP), Family History of Negative (FHN), Family History Density (FHD), Age of Onset of Problem Drinking (AOO).

HOW TO CITE THIS ARTICLE: Palaniappan H, James AGW, Annamalai A. Correlation between severity of alcohol dependence with age of onset and family history among urban alcoholics: a cross-sectional study. J. Evolution Med. Dent. Sci. 2016;5 (52):3452-3457, DOI: $10.14260 /$ jemds/2016/796

\section{INTRODUCTION}

Alcoholism is a very serious problem in our community. Over sixty medical conditions are directly or indirectly attributed to the use of alcohol. Alcoholism is reported to cause $3.5 \%$ of the global death and disability. High incidence of crime is also linked to problematic alcohol use. Alcohol consumption cause increased risk of mortality from several types of cancers, heart disease, and liver cirrhosis.

Financial or Other, Competing Interest: None.

Submission 13-05-2016, Peer Review 07-06-2016.

Acceptance 13-06-2016, Published 30-06-2016.

Corresponding Author:

Alexander Gnanadurai William James,

Professor, Department of Psychiatry,

Govt. Stanley Medical College,

Chennai.

E-mail: drdralex@gmail.com

DOI: $10.14260 /$ jemds/2016/796
According to Lancet's Global Disease Burden Study, 2010, 4.9 million deaths and $5.5 \%$ of the total DALYs lost worldwide is linked to problematic alcohol usage. ${ }^{1}$ WHO Global Status Report on alcohol and health, 2014 attributes 3.3 million deaths annually to increased alcohol dependence. ${ }^{2}$ It is one of the major reasons for the deaths in the productive age groups of 15-49 (Lim, Stephen S et al, 2013). ${ }^{1}$ About one third of population in India suffers below the poverty line because of the extensive consumption of alcohol (Saxena, Shekhar, Raj Sharma, and Maulik, 2003). ${ }^{3}$ Recent trends in alcohol consumption are alarming, as the average age of first drink has come down from 28 years to 17 years between 1980 and 2007.

Lewis et al (1983) demonstrated that male sex; antisocial personality and family history of alcoholism increased the risk of severity of alcoholism. ${ }^{4}$ 
Subjects with family history of alcoholism had an increased severity of alcohol-related problems; however, it was difficult to interpret whether this propensity is genetic or environmental or a combination of the two. Previous studies done internationally indicate that alcoholism is more severe when familial. Also, there is evidence that the familiality also impacts on the age of onset (Cloninger CR, 1987). ${ }^{5}$ Additionally, it is established that age is inversely proportional to the severity of alcoholism (Irwin M, Schuckit M, Smith TL, 1990). ${ }^{6}$ This has led to further explorations into what is inherited (Farren CK, Tipton KF, 1999). ${ }^{7}$ and what mediates the heightened severity in familial alcoholism (Cloninger CR, 1987). ${ }^{5}$

\section{Family History and Severity of Alcohol Dependence}

A study by among 2215 Navy recruits from alcohol rehabilitation program using a self-reported biological questionnaire revealed that more the number of first-degree relatives worse the outcome of alcoholism at different points of time (Frances RJ, Bucky S, Alexopoulos GS, 1984). ${ }^{8} \mathrm{~A}$ multicentric study of subjects from alcoholism treatment centre by Penick et al in 1987 showed that 65\% FHP had significantly more medical problems than FHN. ${ }^{9}$ Grant et al in 1994 found that family history of alcoholism had a substantial effect on the development of alcohol dependence over the life span. ${ }^{10}$ High risk children had early age of onset and alcohol dependence (Hill S.Y. et al, 2000). ${ }^{11}$

\section{Severity of Alcohol Dependence and Age of onset of Alcohol use}

Early onset of alcohol use is associated with childhood criminality and other drug use (Irwin, Schuckit and Smith, 1990; Gruber et al, 1996).6,12 A significant correlation was observed between AOO and severity (Pickens et al, 1991).13

\section{The Study Specifically Aims}

1. To compare the severity of alcohol dependence in two groups divided on the basis of presence or absence of family history of alcohol use in the first and seconddegree relatives.

2. To assess the age of onset of alcohol use and to correlate this with severity of alcohol dependence.

\section{METHODS}

For a period of six months, we conducted a cross-sectional study among 200 male subjects aged between 20-50 years who reported alcohol and drug dependence clinic of a tertiary care hospital in Chennai, Tamilnadu State with problem drinking in the past one year scoring more than 8 on Alcohol Use Disorder Inventory Test (AUDIT).

\section{Tools Used in this Study}

\section{Alcohol Use Disorder Identification Test (AUDIT) (Bohn} MJ, Babor TF, Kranzler HR, 1995). ${ }^{14}$

AUDIT is a 10 -item screening questionnaire developed by W.H.O. to identify persons whose alcohol consumption has become harmful to their health. It has a good test retest reliability, internal consistency and validity. Srinivasan and Mary (2000). ${ }^{15}$ and Sateesh Babu and Sen Gupta (1997). ${ }^{16}$ have used AUDIT in Indian Context.

\section{Clinical Institute Withdrawal Assessment for Alcohol (CIWA-AD) (Sullivan JT et al, 1989). ${ }^{17}$}

It is 8-item scale for clinical quantification of the severity of the alcohol withdrawal syndrome. A score of less than or equal to 8 indicates that the withdrawal symptoms have either subsided or very minimal. Manikant et al (1992) have used CIWA in the Indian context. 18

\section{Severity of Alcohol Dependence Questionnaire} (Stockwell T, Murphy D, Hodgson R, 1983).19

This questionnaire was developed to provide a brief and replicable method of assessing alcohol dependence. It is a 20item self-completion questionnaire in which the respondents are required to focus upon a recent month typical of their heavy drinking. Each item is rated upon a four-point scale (Almost never, sometimes often, and nearly always) and responses are scored as $0,1,2$, or 3 accordingly. Thus, the range of total score is from $0-60$. A score of 31 or higher is correlated with severe alcohol dependence and less than 30 is correlated with mild-to-moderate dependence. It has a very high degree of test and retest reliability and a very good evidence of construct and concurrent validity.

\section{Family History Method}

In this method, the subjects are divided into family history positive and negative groups. Scott. F. Stoltenberg (1998). ${ }^{20}$ proposed a new family history measure called the Family History Density (FHD), which is a modification of Family Pattern of Alcoholism (FPA). In this method, weighted points were given to the alcoholic family members (both parents and all four grandparents). The non-alcoholic relatives were given a score of zero, parents were given a score of 0.5 , and grandparents were given 0.25 . The scores were summed over the six ancestors to obtain the FHD score, which ranged from $0-2$. The scoring system is based on the familial relatedness, which is functionally same as genetic relatedness and theoretically explicit because it takes into account the influence of family environment (parents are expected to influence the proband directly than the grandparents). Mothers were also included in this scoring system since FHD is an index of biopsychosocial measure, which includes the deleterious effects of drinking during pregnancy, and not limited to foetal alcohol syndrome.

We have considered both the conventional dichotomy method and the Family History Density Method. These methods were chosen in order to compare and contrast the methodological issues.

Schedule for Clinical Assessment in Neuropsychiatry (SCAN) (Aboraya, Tien, Stevenson and Crosby, 1997). ${ }^{21}$

SCAN is a set of instrument aimed at assessing, measuring, and classifying psychopathology and syndromal diagnosis. The current version is 2.1. Alcohol section was used to get the age of onset of harmful use and to establish a diagnosis of alcohol dependence syndrome based on the $10^{\text {th }}$ edition of international classification of diseases and screening section of this assessment was used to rule out any major psychiatric illness such as psychosis, bipolar affective disorder, dementia, and amnesic syndromes.

\section{Age of Onset of Problem Drinking (AO0)}

Our operational definition was "The age in which drinking first began to have an effect on the subjects' life of which he or she did not approve" (Johnson et al, 2000).22 We assessed the age of onset from the alcohol section SCAN.

\section{Data Analysis}

The data was analysed using a computerized Statistical Software programme (SPSS version 20.0 for windows). 
Descriptive statistics was used to describe the sociodemographic variables. Student t-test was used to compare between ordinal groups. Pearson's correlation was used for assessing the correlation between the variables.

\section{RESULTS}

Table 1 summarizes the socio-demographic characteristics and the current age of onset. Their current ages ranged from 20-55 yrs. 123 subjects were Family History Positive (FHP) and 77 were Family History of Negative (FHN). In the FHP group, 8 (4\%) were in the 20-25 yrs. of current age 21 $(10.5 \%)$ were in the $26-30$ age group, $22(11 \%)$ were in the 31-35 age group, 17 (8.5\%) were in the 36-40 age group, 23 $(11.5 \%)$ were in the $41-46$ age group and $32(16 \%)$ were in the 46-50 age group. In the FNH group, $1(0.5 \%)$ are in the 20-25 yrs. of current age, 3 (1.5\%) were in the 26-30 age group, $10(5 \%)$ were in the 31-35 age group, 18 (9\%) were in the 36-40 age group, $16(8 \%)$ were in the $41-45$ age group, and $29(14.5 \%)$ were in the $46-50$ age group.

\begin{tabular}{|c|c|c|c|c|c|c|c|c|c|}
\hline $\begin{array}{c}\text { Current } \\
\text { Age }\end{array}$ & $20-25$ & $26-30$ & $31-35$ & $36-40$ & $41-45$ & $46-50$ & Total & Mean & SD \\
\hline $\mathrm{AOO}<25$ & $\begin{array}{c}9 \\
(4.5 \%)\end{array}$ & $\begin{array}{c}18 \\
(9 \%)\end{array}$ & $\begin{array}{c}21 \\
(10.5 \%)\end{array}$ & $\begin{array}{c}20 \\
(10 \%)\end{array}$ & $\begin{array}{c}20 \\
(10 \%)\end{array}$ & $\begin{array}{c}28 \\
(14 \%)\end{array}$ & $\begin{array}{c}116 \\
(58 \%)\end{array}$ & 19.33 & 6.12 \\
\hline $\begin{array}{l}\mathrm{AOO} \\
>25\end{array}$ & 0 & $\begin{array}{c}6 \\
(3 \%) \\
\end{array}$ & $\begin{array}{c}11 \\
(5.5 \%) \\
\end{array}$ & $\begin{array}{c}15 \\
(7.5 \%)\end{array}$ & $\begin{array}{c}19 \\
(9.5 \%)\end{array}$ & $\begin{array}{c}33 \\
(16.5 \%) \\
\end{array}$ & $\begin{array}{c}84 \\
(42 \%) \\
\end{array}$ & 14 & 11.45 \\
\hline FHP & $\begin{array}{c}8 \\
(4 \%) \\
\end{array}$ & $\begin{array}{c}21 \\
(10.5 \%)\end{array}$ & $\begin{array}{c}22 \\
(11 \%)\end{array}$ & $\begin{array}{c}17 \\
(8.5 \%)\end{array}$ & $\begin{array}{c}23 \\
(11.5 \%) \\
\end{array}$ & $\begin{array}{c}32 \\
(16 \%) \\
\end{array}$ & $\begin{array}{c}123 \\
(68.5 \%) \\
\end{array}$ & 20.5 & 7.87 \\
\hline FHN & $\begin{array}{c}1 \\
(0.5 \%) \\
\end{array}$ & $\begin{array}{c}3 \\
(1.5 \%) \\
\end{array}$ & $\begin{array}{c}10 \\
(5 \%)\end{array}$ & $\begin{array}{c}18 \\
(9 \%) \\
\end{array}$ & $\begin{array}{c}16 \\
(8 \%)\end{array}$ & $\begin{array}{c}29 \\
(14.5 \%) \\
\end{array}$ & $\begin{array}{c}77 \\
(13.5 \%) \\
\end{array}$ & 12.83 & 10.42 \\
\hline $\begin{array}{c}\text { FHD 0 } \\
\text { Group 1 }\end{array}$ & $\begin{array}{c}1 \\
(0.5 \%)\end{array}$ & $\begin{array}{c}3 \\
(1.5 \%)\end{array}$ & $\begin{array}{c}10 \\
(5 \%)\end{array}$ & $\begin{array}{c}18 \\
(9 \%)\end{array}$ & $\begin{array}{c}16 \\
(8 \%)\end{array}$ & $\begin{array}{c}29 \\
(14.5 \%)\end{array}$ & $\begin{array}{c}77 \\
(13.5 \%)\end{array}$ & 12.83 & 10.42 \\
\hline $\begin{array}{c}.25-.5 \\
\text { Group } 2 \\
\end{array}$ & $\begin{array}{c}5 \\
(2.5 \%) \\
\end{array}$ & $\begin{array}{c}11 \\
(5.5 \%)\end{array}$ & $\begin{array}{c}13 \\
(6.5 \%) \\
\end{array}$ & $\begin{array}{c}11 \\
(5.5 \%)\end{array}$ & $\begin{array}{c}14 \\
(7 \%) \\
\end{array}$ & $\begin{array}{c}16 \\
(8 \%) \\
\end{array}$ & $\begin{array}{c}70 \\
(35 \%) \\
\end{array}$ & 11.67 & 3.78 \\
\hline $\begin{array}{c}.75-2 \\
\text { Group } 3\end{array}$ & $\begin{array}{c}3 \\
(1.5 \%)\end{array}$ & $\begin{array}{c}10 \\
(5 \%)\end{array}$ & $\begin{array}{c}9 \\
(4.5 \%)\end{array}$ & $\begin{array}{c}6 \\
(3 \%)\end{array}$ & $\begin{array}{c}9 \\
(4.5 \%)\end{array}$ & $\begin{array}{c}16 \\
(8 \%)\end{array}$ & $\begin{array}{c}53 \\
(26.5 \%)\end{array}$ & 8.83 & 4.36 \\
\hline
\end{tabular}

\begin{tabular}{|c|c|c|c|c|c|c|c|c|c|}
\hline $\begin{array}{l}\text { Severity } \\
\text { Mid-Mod }\end{array}$ & $\begin{array}{c}1 \\
(0.5 \%)\end{array}$ & $\begin{array}{c}2 \\
(1 \%)\end{array}$ & $\begin{array}{c}3 \\
(1.5 \%) \\
\end{array}$ & $\begin{array}{c}5 \\
(2.5 \%) \\
\end{array}$ & $\begin{array}{c}2 \\
(1 \%)\end{array}$ & $\begin{array}{c}7 \\
(3.5 \%) \\
\end{array}$ & $\begin{array}{c}20 \\
(10 \%)\end{array}$ & 3.33 & 2.25 \\
\hline Severe & $\begin{array}{c}8 \\
(4 \%)\end{array}$ & $\begin{array}{c}22 \\
(11 \%)\end{array}$ & $\begin{array}{c}29 \\
(14.5 \%)\end{array}$ & $\begin{array}{c}30 \\
(15 \%)\end{array}$ & $\begin{array}{c}37 \\
(18.5 \%)\end{array}$ & $\begin{array}{c}54 \\
(27 \%)\end{array}$ & $\begin{array}{c}180 \\
(90 \%)\end{array}$ & 30 & 15.32 \\
\hline $\begin{array}{l}\text { Income } \\
<1000\end{array}$ & $\begin{array}{c}2 \\
(1 \%) \\
\end{array}$ & $\begin{array}{c}5 \\
(2.5 \%) \\
\end{array}$ & $\begin{array}{c}4 \\
(2 \%) \\
\end{array}$ & $\begin{array}{c}2 \\
(1 \%)\end{array}$ & $\begin{array}{c}2 \\
(1 \%) \\
\end{array}$ & $\begin{array}{c}5 \\
(2.5 \%) \\
\end{array}$ & $\begin{array}{c}20 \\
(10 \%)\end{array}$ & 19.5 & 8.38 \\
\hline $\begin{array}{l}1001- \\
5000\end{array}$ & $\begin{array}{c}6 \\
(3 \%)\end{array}$ & $\begin{array}{c}15 \\
(7.5 \%)\end{array}$ & $\begin{array}{c}21 \\
(10.5 \%)\end{array}$ & $\begin{array}{c}27 \\
(13.6 \%)\end{array}$ & $\begin{array}{c}19 \\
(9.5 \%)\end{array}$ & $\begin{array}{c}29 \\
(14.6 \%)\end{array}$ & $\begin{array}{c}117 \\
(58.8 \%)\end{array}$ & 19.5 & 8.38 \\
\hline $\begin{array}{l}5001- \\
10000\end{array}$ & 0 & $\begin{array}{c}2 \\
(1 \%)\end{array}$ & $\begin{array}{c}5 \\
(2.5 \%)\end{array}$ & $\begin{array}{c}2 \\
(1 \%)\end{array}$ & $\begin{array}{c}13 \\
(6.5 \%)\end{array}$ & $\begin{array}{c}17 \\
(8.5 \%)\end{array}$ & $\begin{array}{c}39 \\
(19.6 \%)\end{array}$ & 6.5 & 6.89 \\
\hline$>10001$ & $\begin{array}{c}1 \\
(0.5 \%)\end{array}$ & $\begin{array}{c}2 \\
(1 \%)\end{array}$ & $\begin{array}{c}1 \\
(0.5 \%)\end{array}$ & $\begin{array}{c}4 \\
(2 \%)\end{array}$ & $\begin{array}{c}5 \\
(2.5 \%)\end{array}$ & $\begin{array}{c}10 \\
(5 \%)\end{array}$ & $\begin{array}{c}23 \\
(11.6 \%)\end{array}$ & 3.83 & 3.43 \\
\hline
\end{tabular}

\begin{tabular}{|c|c|c|c|c|c|c|c|c|c|}
\hline $\begin{array}{c}\text { Current } \\
\text { Age }\end{array}$ & $20-25$ & $26-30$ & $31-35$ & $36-40$ & $41-45$ & $46-50$ & Total & Mean & SD \\
\hline Married & $\begin{array}{c}3 \\
(1.5 \%)\end{array}$ & $\begin{array}{c}17 \\
(8.5 \%)\end{array}$ & $\begin{array}{c}32 \\
(16 \%)\end{array}$ & $\begin{array}{c}35 \\
(17.5 \%)\end{array}$ & $\begin{array}{c}38 \\
(19 \%)\end{array}$ & $\begin{array}{c}61 \\
(30.5 \%)\end{array}$ & $\begin{array}{c}186 \\
(93 \%)\end{array}$ & 31 & 19.73 \\
\hline Single & $\begin{array}{c}6 \\
(3 \%)\end{array}$ & $\begin{array}{c}7 \\
(3.5 \%)\end{array}$ & 0 & 0 & $\begin{array}{c}1 \\
(0.5 \%)\end{array}$ & 0 & $\begin{array}{c}14 \\
(7 \%)\end{array}$ & 2.33 & 3.27 \\
\hline Joint & $\begin{array}{c}1 \\
(0.5 \%)\end{array}$ & $\begin{array}{c}2 \\
(1 \%)\end{array}$ & $\begin{array}{c}3 \\
(1.5 \%)\end{array}$ & $\begin{array}{c}1 \\
(0.5 \%)\end{array}$ & 0 & $\begin{array}{c}3 \\
(1.5 \%) \\
\end{array}$ & $\begin{array}{c}10 \\
(5 \%)\end{array}$ & 1.67 & 1.21 \\
\hline Extended & $\begin{array}{c}1 \\
(0.5 \%)\end{array}$ & $\begin{array}{c}4 \\
(2 \%)\end{array}$ & $\begin{array}{c}4 \\
(2 \%)\end{array}$ & $\begin{array}{c}1 \\
(0.5 \%)\end{array}$ & $\begin{array}{c}1 \\
(0.5 \%)\end{array}$ & $\begin{array}{c}3 \\
(1.5 \%)\end{array}$ & $\begin{array}{c}14 \\
(7 \%)\end{array}$ & 2.33 & 1.51 \\
\hline Alone & 0 & $\begin{array}{c}1 \\
(0.5 \%) \\
\end{array}$ & 0 & 0 & 0 & 0 & $\begin{array}{c}1 \\
(0.5 \%) \\
\end{array}$ & 0.17 & 0.41 \\
\hline Nuclear & $\begin{array}{c}7 \\
(3.5 \%)\end{array}$ & $\begin{array}{c}17 \\
(8.5 \%)\end{array}$ & $\begin{array}{c}25 \\
(12.5 \%)\end{array}$ & $\begin{array}{c}33 \\
(16.5 \%)\end{array}$ & $\begin{array}{c}38 \\
(19 \%)\end{array}$ & $\begin{array}{c}55 \\
(27.5 \%)\end{array}$ & $\begin{array}{c}175 \\
(87.5 \%)\end{array}$ & $\begin{array}{c}29.1 \\
7\end{array}$ & 16.83 \\
\hline $\begin{array}{c}\text { Occupation } \\
\text { Labourer }\end{array}$ & $\begin{array}{c}5 \\
(2.5 \%)\end{array}$ & $\begin{array}{c}10 \\
(5 \%)\end{array}$ & $\begin{array}{c}13 \\
(6.5 \%)\end{array}$ & $\begin{array}{c}11 \\
(5.5 \%)\end{array}$ & $\begin{array}{c}10 \\
(5 \%)\end{array}$ & $\begin{array}{c}15 \\
(7.5 \%)\end{array}$ & $\begin{array}{c}64 \\
(32 \%)\end{array}$ & $\begin{array}{c}10.6 \\
7\end{array}$ & 3.39 \\
\hline Farmer & $\begin{array}{c}1 \\
(0.5 \%) \\
\end{array}$ & $\begin{array}{c}2 \\
(1 \%)\end{array}$ & $\begin{array}{c}3 \\
(1.5 \%) \\
\end{array}$ & $\begin{array}{c}5 \\
(2.5 \%) \\
\end{array}$ & $\begin{array}{c}2 \\
(1 \%)\end{array}$ & $\begin{array}{c}9 \\
(4.5 \%) \\
\end{array}$ & $\begin{array}{c}22 \\
(11 \%)\end{array}$ & 3.67 & 2.94 \\
\hline Professional & 0 & $\begin{array}{c}3 \\
(1.5 \%)\end{array}$ & $\begin{array}{c}3 \\
(1.5 \%)\end{array}$ & $\begin{array}{c}5 \\
(2.5 \%)\end{array}$ & $\begin{array}{c}7 \\
(3.5 \%)\end{array}$ & $\begin{array}{c}5 \\
(2.5 \%)\end{array}$ & $\begin{array}{c}23 \\
(11.5 \%)\end{array}$ & 3.83 & 2.40 \\
\hline
\end{tabular}




\begin{tabular}{|c|c|c|c|c|c|c|c|c|c|}
\hline Service & 0 & $\begin{array}{c}1 \\
(0.5 \%) \\
\end{array}$ & $\begin{array}{c}1 \\
(0.5 \%)\end{array}$ & $\begin{array}{c}3 \\
(1.5 \%) \\
\end{array}$ & $\begin{array}{c}7 \\
(3.5 \%) \\
\end{array}$ & $\begin{array}{c}10 \\
(5 \%)\end{array}$ & $\begin{array}{c}22 \\
(11 \%) \\
\end{array}$ & 3.67 & 3.98 \\
\hline Employee & $\begin{array}{c}1 \\
(0.5 \%)\end{array}$ & $\begin{array}{c}4 \\
(2 \%)\end{array}$ & $\begin{array}{c}4 \\
(2 \%)\end{array}$ & $\begin{array}{c}4 \\
(2 \%)\end{array}$ & $\begin{array}{c}8 \\
(4 \%)\end{array}$ & $\begin{array}{c}14 \\
(7 \%)\end{array}$ & $\begin{array}{c}35 \\
(17 \%)\end{array}$ & 5.83 & 4.58 \\
\hline Student & $\begin{array}{c}1 \\
(0.5 \%)\end{array}$ & 0 & 0 & 0 & $\begin{array}{c}1 \\
(0.5 \%)\end{array}$ & 0 & $\begin{array}{c}2 \\
(1 \%)\end{array}$ & 1.33 & 2.34 \\
\hline Businessmen & $\begin{array}{c}1 \\
(0.5 \%) \\
\end{array}$ & $\begin{array}{c}4 \\
(2 \%) \\
\end{array}$ & $\begin{array}{c}6 \\
(3 \%) \\
\end{array}$ & $\begin{array}{c}6 \\
(3 \%) \\
\end{array}$ & $\begin{array}{c}4 \\
(2 \%) \\
\end{array}$ & $\begin{array}{c}6 \\
(3 \%) \\
\end{array}$ & $\begin{array}{c}27 \\
(13.5 \%) \\
\end{array}$ & 4.5 & 1.97 \\
\hline Retired & 0 & 0 & 0 & 0 & 0 & $2(1 \%)$ & $2(1 \%)$ & 0.33 & 0.82 \\
\hline $\begin{array}{c}\text { Education } \\
\text { Primary }\end{array}$ & $\begin{array}{c}3 \\
(1.5 \%)\end{array}$ & $\begin{array}{c}4 \\
(2 \%) \\
\end{array}$ & $\begin{array}{c}7 \\
(3.5 \%) \\
\end{array}$ & $\begin{array}{c}9 \\
(4.5 \%) \\
\end{array}$ & $\begin{array}{c}7 \\
(3.5 \%) \\
\end{array}$ & $\begin{array}{c}10 \\
(5 \%)\end{array}$ & $\begin{array}{c}40 \\
(20 \%) \\
\end{array}$ & 6.67 & 2.73 \\
\hline Secondary & $\begin{array}{c}6 \\
(3 \%) \\
\end{array}$ & $\begin{array}{c}8 \\
(4 \%) \\
\end{array}$ & $\begin{array}{c}19 \\
(9.5 \%) \\
\end{array}$ & $\begin{array}{c}14 \\
(7 \%) \\
\end{array}$ & $\begin{array}{c}21 \\
(10 \%)\end{array}$ & $\begin{array}{c}35 \\
(17.5 \%) \\
\end{array}$ & $\begin{array}{c}103 \\
(51.5 \%) \\
\end{array}$ & $\begin{array}{c}17.7 \\
0 \\
\end{array}$ & 10.53 \\
\hline Graduate & 0 & $\begin{array}{c}5 \\
(2.5 \%) \\
\end{array}$ & $\begin{array}{c}1 \\
(0.5 \%)\end{array}$ & $\begin{array}{c}8 \\
(4 \%)\end{array}$ & $\begin{array}{c}9 \\
(4.5 \%) \\
\end{array}$ & $\begin{array}{c}9 \\
(4.5 \%) \\
\end{array}$ & $\begin{array}{c}32 \\
(16 \%) \\
\end{array}$ & 3.33 & 4.03 \\
\hline Diploma & 0 & 0 & $\begin{array}{c}4 \\
(2 \%)\end{array}$ & $\begin{array}{c}1 \\
(0.5 \%)\end{array}$ & $\begin{array}{c}1 \\
(0.5 \%)\end{array}$ & $\begin{array}{c}4 \\
(2 \%)\end{array}$ & $\begin{array}{c}10 \\
(5 \%)\end{array}$ & 1.67 & 1.86 \\
\hline $\begin{array}{c}\text { No } \\
\text { Education }\end{array}$ & 0 & $\begin{array}{c}7 \\
(3.5 \%)\end{array}$ & $\begin{array}{c}1 \\
(0.5 \%)\end{array}$ & $\begin{array}{c}3 \\
(1.5 \%)\end{array}$ & $\begin{array}{c}1 \\
(0.5 \%)\end{array}$ & $\begin{array}{c}3 \\
(1.5 \%)\end{array}$ & $\begin{array}{c}15 \\
(7.5 \%)\end{array}$ & 2.30 & 2.51 \\
\hline
\end{tabular}

Family history density consisted of three groups; they included Group1 where the total FH score was 0, Group 2 where FH score was between 0.25-0.5 and Group 3 where the score was $0.75-2$. The FDH 0 group had 77 subjects, $0.25-0.5$ had 70 subjects and $0.75-2$ group had 53 subjects. In the Group 2, 5 (2.5\%) were present in the 20-25 yrs. of current age, $11(5.5 \%)$ were in the $36-40$ age group, $14(7 \%)$ were in the $41-46$ age group and $16(8 \%)$ were in the $46-50$ group. In the Group 3, $3(1.5 \%)$ were present in the $20-25$ yrs. of current age, $10(5 \%)$ were in the 26-30 age group, 9 (4.5\%) were in the 31-35 age group, $6(3 \%)$ were in the 36-40 age group, $9(4.5 \%)$ were in the $41-46$ age group and $16(8 \%)$ were in the 46-50 group.

In the Family History Density scoring all the 6 direct ancestors were taken into analysis and other family members were excluded. They included Father, Mother, Paternal Grandfather, Paternal Grandmother, Maternal Grandfather, and Maternal Grandmother. The Table 2 shows the status of Family Members positive and negative in the each FHD groups.

\begin{tabular}{|c|c|c|c|c|c|}
\hline FHD & Status & Group 1 & Group2 & Group 3 & Total \\
\hline \multirow{2}{*}{ Father } & Positive & 0 & $55(27.5 \%)$ & $53(26.5 \%)$ & $108(54 \%)$ \\
\cline { 2 - 6 } & Negative & $77(38.5 \%)$ & $15(7.5 \%)$ & 0 & $92(46 \%)$ \\
\hline \multirow{2}{*}{ Mother } & Positive & 0 & 0 & $10(5 \%)$ & $10(5 \%)$ \\
\cline { 2 - 6 } & Negative & $77(38.5 \%)$ & $70(35 \%)$ & $43(21.5 \%)$ & $190(95 \%)$ \\
\hline \multirow{2}{*}{ Paternal Grand Father } & Positive & 0 & $10(5 \%)$ & $42(21 \%)$ & $52(26 \%)$ \\
\cline { 2 - 6 } & Negative & $77(38.5 \%)$ & $60(30 \%)$ & $11(5.5 \%)$ & $148(74 \%)$ \\
\hline \multirow{2}{*}{ Paternal Grand Mother } & Positive & 0 & 0 & $6(3 \%)$ & $6(3 \%)$ \\
\cline { 2 - 6 } & Negative & $77(38.5 \%)$ & $70(35 \%)$ & $47(23.5 \%)$ & $194(97 \%)$ \\
\hline \multirow{2}{*}{ Maternal Grand Father } & Positive & 0 & $8(4 \%)$ & $30(15 \%)$ & $38(19 \%)$ \\
\cline { 2 - 6 } & Negative & $77(38.5 \%)$ & $62(31 \%)$ & $23(11.5 \%)$ & $162(81 \%)$ \\
\hline \multirow{2}{*}{ Maternal Grand Mother } & Positive & 0 & 0 & $9(4.5 \%)$ & $9(4.5 \%)$ \\
\cline { 2 - 6 } & Negative & $77(38.5 \%)$ & $70(35 \%)$ & $44(22 \%)$ & $191(95.5 \%)$ \\
\hline \multicolumn{2}{|c|}{ FHD=Family History Density; GROUP1=FHD Score of Zero; GROUP2=FHD Score } \\
Between 0.25-0.5; Group 3=FHD Score Between 0.75-2
\end{tabular}

\begin{tabular}{|c|c|c|c|c|c|}
\hline $\begin{array}{c}\text { Age of } \\
\text { Onset }\end{array}$ & No. & $\begin{array}{c}\text { Mean } \\
\text { Current } \\
\text { Age }\end{array}$ & S & $\begin{array}{c}\text { Mean } \\
\text { SADQ }\end{array}$ & S \\
\hline$<25 y r s$. & 116 & $\begin{array}{c}38.08 \\
(\mathrm{SD}=8.56)\end{array}$ & $\mathrm{P}=0.000$ & $\begin{array}{c}44.73 \\
(\mathrm{SD}=10.66)\end{array}$ & $\mathrm{P}=0.001$ \\
\hline $\begin{array}{c}>0 \mathrm{R} \\
\text { EQUAL } \\
\text { TO } 25\end{array}$ & 84 & $\begin{array}{c}42.56 \\
(\mathrm{SD}=6.76)\end{array}$ & & $\begin{array}{c}39.24 \\
(\mathrm{SD}=11.63)\end{array}$ & \\
\hline \multicolumn{6}{|c|}{ S=Significance } \\
\hline \multicolumn{6}{|c|}{ Table 3: Compares the Age of Onset with } \\
Current Age and Score. SADQ
\end{tabular}

The age of onset was divided into two groups. First group consisted of A00 $<25$ yrs. and the second group was A00 >25 yrs.
It can be seen from the Table 3 that the mean severity scores were significantly different between the early age of onset and late age of onset groups.

In the 20-25 yrs. of current age, $18(9 \%)$ were in the 26 30 age group, $21(10.5 \%)$ were in the $31-35$ age group, 20 $(10 \%)$ were in the 36-40 age group, $20(10 \%)$ in the 41-46 age group and $28(14 \%)$ were in the $46-50$ group. In the second group, there were none in the 20-25 yrs. of current age, $6(3 \%)$ were in the 26-30 age group, 11 (5.5\%) were in the 31-35 age group, 15 (7.5\%) were in the 36-40 age group, $19(9.5 \%)$ were in the $41-46$ age group, and 33 (16.5\%) were in the 46-50 group.

The severity of alcohol dependence as assessed by SADQ, was divided into two groups based on a cut-off point at 30 . 
The first group with a score of less than 30 belonged to the mild-to-moderate group and the second group with a score of more than 30 belonged to the severe group. In the mild-to-moderate group, $1(0.5 \%) 20-25$ yrs. of current age, 2 $(1 \%)$ were in the $26-30$ age group, $3(1.5 \%)$ were in the 31 35 age group, 5 (2.5\%) were in the $36-40$ age group, 2 (1\%) were in the 41-46 age group, and 7 (3.5\%) were in 46-50 group. In the severe group, 8 (4\%) 20-25 yrs. of current age, $22(11 \%)$ were in the $26-30$ age group, $29(14.5 \%)$ were in the $31-35$ age group, 30 (15\%) were in the $36-40$ age group, $37(18.5 \%)$ were in the $41-46$ age group, and $54(27.5 \%)$ were in the 46-40 age group.

\begin{tabular}{|c|c|c|c|c|c|c|}
\hline Family History & No & Mean Current Age & Mean Age of Onset & $\mathbf{S}$ & Mean SADQ & $\mathbf{S}$ \\
\hline Positive & 123 & $\begin{array}{c}38.62 \\
(\mathrm{SD}=8.59) \mathrm{NS}\end{array}$ & $\begin{array}{c}22.89 \\
(\mathrm{SD}=4.61)\end{array}$ & $\mathrm{P}=0.000$ & $\begin{array}{c}44.59 \\
(\mathrm{SD}=10.79)\end{array}$ & $P=0.001$ \\
\hline Negative & 77 & $\begin{array}{c}42.12 \\
(\mathrm{SD}=5.90) \\
\end{array}$ & $\begin{array}{c}26.51 \\
(\mathrm{SD}=5.90)\end{array}$ & & $\begin{array}{c}38.96 \\
(\mathrm{SD}=11.50)\end{array}$ & \\
\hline
\end{tabular}

Table 4 shows the association of FH (Dichotomy) with current age, mean A00, and mean SADQ score. The mean current age in the FHP was $38.61 \pm 8.59$ and $42.12 \pm 6.90$ in FHN. The mean AOO in the FHP was $22.89 \pm 4.61$ and in the FHN was $26.51 \pm 26.51$ and was significantly different from each other $(\mathrm{P}<0.000)$. The mean SADQ score were $44.59 \pm 10.79$ in FHP and $38.96 \pm 11.50$ in the FHN. This was also significantly different between the two groups $(\mathrm{P}<0.001)$.

\begin{tabular}{|c|c|c|c|}
\hline $\begin{array}{c}\text { Factor } \\
\text { Studied }\end{array}$ & $\begin{array}{c}\text { Variables } \\
\text { Studied }\end{array}$ & $\begin{array}{c}\text { Pearson's } \\
\text { Correlation }\end{array}$ & Significance \\
\hline Severity & Current age & -0.075 & $\begin{array}{c}\text { Not } \\
\text { Significant }\end{array}$ \\
\hline Severity & $\begin{array}{c}\text { Family } \\
\text { history } \\
\text { Density }\end{array}$ & -0.287 & $\mathrm{P}=0.01$ \\
\hline Severity & Age of onset & -0.346 & $\mathrm{P}=0.01$ \\
\hline \multicolumn{3}{|c|}{ Table 5: Showing the Correlation of Severity } \\
with Other Variables Studied \\
\hline
\end{tabular}

The Table 5 shows the correlation between FHD, current age, age of onset severity. The mean current age in the group 1 was $42.2 \pm 6.90$, Group 2 was $38.72 \pm 8.86$ in the last group. The correlation was not significantly significant. The mean A00 was in the Group1 was 26.51 \pm 5.90 , Group 2 was $23.29 \pm 5.11$ yrs. and $22.36 \pm 3.82$ yrs. In the last group, the correlation between FHD and mean AOO were statistically significant $(\mathrm{p}=0.001)$. The mean SADQ in the Group 1 was $38.9 \pm 11.50$, Group 2 was $43.43 \pm 10.78$, and $46.13 \pm 10.71$ in the last group. The relationship between FHD and the mean SADQ scores were also significant $(p=0.01)$. On analysing, the partial correlations, the significance of FHD with severity increased from $\mathrm{p}=0.01$ to $\mathrm{p}=0.000$ (Coefficient of -0.2931 and $\mathrm{df}=197)$, after controlling for AOO and the significance value of AOO and Severity remained the same after controlling FHD.

\section{DISCUSSION}

The two key findings of this study are that alcoholism severity is related to family history of alcoholism and also age of onset of alcoholism independent of each other. The relationship with severity with positive family history of alcoholism is in agreement with many studies. $23,24,25$ This relationship holds good despite varying settings, samples and variety of assessment methods. Keenan et al (1997). ${ }^{26}$ study had only 36 subjects and may not have been powered to address this issue adequately. Schacter et al did have a trend in the direction of greater severity in presence of positive family history. Their samples were derived from those arrested for public drunkenness. The study by Hingson. (27) et al reports that those who begin drinking before the age of 14 years are more likely to experience alcohol dependence within 10 years of the first drink, even after controlling for socio-demographic data, smoking, illicit drug use, childhood antisocial behaviour, depression, and family alcoholism history. Meghan E et al (28) found in 295 adolescent drinkers the early onset of alcohol drinking was associated with increased severity. Using data obtained in the 1992 National Longitudinal Alcohol Epidemiologic Survey, Grant BF.(29) demonstrated that regardless of the family history of alcoholism, respondents with an earlier age of drinking onset were more likely to become alcohol dependent compared with respondents with a later age of drinking onset.

The important implication of our study is that any preventive measures of alcoholism should start in adolescent period and also target the offspring of alcohol dependent parent.

\section{LIMITATIONS OF THE STUDY}

Although, our original plan was to target a widely ranged sample from a severity point of view by using subjects of varied severity since most of the patients are admitted in deaddiction ward and hence this understandably has skewed the sample towards higher range of severity. We have seen only problem drinkers as per AUDIT criteria. There may be others in the community who may score less on AUDIT, but have frequent use of alcohol. Therefore, this is a study of severity of alcohol dependence in a group of AUDIT defined subjects with harmful use and not a study of all alcohol use. However, different thresholds for screening may be attempted in the community samples so that a wider spectrum of severity can be obtained. Alternatively, a study looking at a large sample with stratified levels of severity can be an improvement on this design.

The patients were screened using stringent criteria by AUDIT to look for problem of hazardous drinking. Even though, we have not blinded this study, the sequence of administration of the SADQ before interviewing the FH itself acted as a "blinding process." This has not been standardised in an Indian context. In fact no measure standardised in an Indian context looking at Severity of alcohol use exists. The psychometric properties apply when it is used as a self-report measure. This remains a limitation of the method.

A study focussed on correlates of severity of alcohol use. A sample with a wider range of severity would increase confidence limits with regard to correlation analysis.

Future studies need to focus on all these issues namelyscreening criteria/populations, which can contribute a less severe sample than obtained from psychiatric wards. 
A community study with less stringent sampling covering a range of severity thresholds could be attempted from medical/surgical populations. Such a design would call for less rigid time constraints than could be afforded by this study.

\section{CONCLUSION}

Adolescent and early adulthood are sensitive periods of an individual's developmental trajectory. Alcohol use at this period causes enormous effect and consequences on individual's health and is associated with automobile crashes, accidental injuries, suicide, violent crime, risky sexual behaviour, alcohol intoxication and dependence. Parental alcoholism influence alcohol use and dependence in the offspring by modelling of drinking behaviour and the establishment of family norms for drinking. Further, it increases the risk for early onset drinking and trajectories of persistent alcohol use and severity among offspring. All clinical and public health interventions at an early stage only i.e. adolescence and early adult period are likely to confer more health benefits on individual and society.

\section{REFERENCES}

1. Stephen LS, Vos T, Flaxman AD, et al. A comparative risk assessment of burden of disease and injury attributable to 67 risk factors and risk factor clusters in 21 regions, 1990-2010: a systematic analysis for the global burden of disease study 2010. The lancet 2013;380(9859):2224-60.

2. World health organization. Global status report on alcohol and health, 2014.

3. Shekhar S, Sharma R, Maulik PK. Impact of alcohol use on poor families: a study from north India. Journal of substance use 2003;8(2):78-84.

4. Lewis CE, Rice J, Helzer JE. Alcoholism and antisocial personality. The Journal of nervous and mental disease 1983;171(2):105-13.

5. Cloninger CR. Recent advances in family studies of alcoholism. Progress in clinical and biological research 1987;241:47.

6. Irwin M, Schuckit M, Smith TL. Clinical importance of age at onset in type 1 and type 2 primary alcoholics. Archives of General Psychiatry 1990;47(4):320-4.

7. Farren CK, Tipton KF. Trait markers for alcoholism: clinical utility. Alcohol and Alcoholism 1999;34(5): 649-65.

8. Frances RJ, Bucky S, Alexopoulos GS. Outcome study of familial and non-familial alcoholism. The American journal of psychiatry 1984;141(11):1469-71.

9. Penick EC, Powell BJ, Bingham SF, et al. A comparative study of familial alcoholism. Journal of Studies on Alcohol 1987;48(2):136-46.

10. Grant BF, Dawson DA. Age at onset of alcohol use and its association with DSM-IV alcohol abuse and dependence: results from the national longitudinal alcohol epidemiologic survey. Journal of substance abuse 1997;9:103-10.

11. Hill SY, Shen S, Lowers L, et al. Factors predicting the onset of adolescent drinking in families at high risk for developing alcoholism. Biological psychiatry 2000; 48(4) : 265-75.

12. Gruber E, DiClemente RJ, Anderson MM, et al. Early drinking onset and its association with alcohol use and problem behaviour in late adolescence. Preventive medicine 1996;25(3):293-300.
13. Pickens RW, Svikis DS, McGue M, et al. Heterogeneity in the inheritance of alcoholism: a study of male and female twins. Archives of General Psychiatry 1991;48(1):19-28.

14. Bohn MJ, Babor TF, Kranzler HR. The alcohol use disorders identification test: validation of a screening instrument for use in medical settings. Journal of studies on alcohol 1995;56(4):423-32.

15. Srinivasan K, Augustine MK. A study of alcohol related physical diseases in general hospital patients. Indian journal of psychiatry 2000;42(3):247-52.

16. Babu RS, Sengupta SN. A study of problem drinkers in a general hospital. Indian journal of psychiatry 1997;39(1):13-7.

17. Sullivan JT, Sykora K, Schneiderman J, et al. Clinical institute withdrawal assessment for,[www]. Canadian Medical Association Journal. Verfügbarunter: http://www. cma. ca/cmaj 1989:160.

18. Manikant S, Tripathi BM, Chavan BS. Utility of ciwa-a in alcohol withdrawal assessment. Indian journal of psychiatry 1992;34(4):347-50.

19. Stockwell T, Murphy D, Hodgson R. The severity of alcohol dependence questionnaire: its use, reliability and validity. British journal of addiction 1983;78(2):145-55.

20. Stoltenberg SF, Mudd SA, Blow FC, et al. Evaluating measures of family history of alcoholism: density versus dichotomy. Addiction 1998;93(10):1511-20.

21. Aboraya A, Tien A, Stevenson J, et al. Schedules for clinical assessment in neuropsychiatry: introduction to WV's mental health community. The West Virginia medical journal 1998;94(6):326-8.

22. Johnson BA, Cloninger CR, Roache JD, et al. Age of onset as a discriminator between alcoholic subtypes in a treatment-seeking outpatient population. The American Journal on Addictions 2000;9(1):17-27

23. Schuckit MA. Subjective responses to alcohol in sons of alcoholics and control subjects. Archives of General Psychiatry 1984;41(9):879-84.

24. Hauser J, Rybakowski J. Three clusters of male alcoholics. Drug and alcohol dependence 1997;48(3):243-50.

25. Assanangkornchai S, Geater AF, Saunders JB, et al. Effects of paternal drinking, conduct disorder and childhood home environment on the development of alcohol use disorders in a Thai population. Addiction 2002;97(2): 217-26.

26. Keenan JP, Freeman PR, Harrell R. The effects of family history, sobriety length, and drinking history in younger alcoholics on P300 auditory-evoked potentials. Alcohol and Alcoholism 1997;32(3):233-9.

27. Hingson RW, Heeren T, Winter MR. Age at drinking onset and alcohol dependence: age at onset, duration, and severity. Arch Paediatr Adolesc Med 2006;160(7):739-46.

28. Meghen E, Kong G, Camenga DR, et al. First drink to first drunk: age of onset and delay to intoxication are associated with adolescent alcohol use and binge drinking. Alcohol Clin Exp Res 2014;38(10):2615-21.

29. Grant BF. The impact of a family history of alcoholism on the relationship between age at onset of alcohol use and DSM-IV alcohol dependence: results from the national longitudinal alcohol epidemiologic survey. Alcohol Health Res World 1998;22:144-7. 